\title{
A Study of Well-Being among Hindu and Muslim Students in Aligarh
}

\author{
Mohd. Ahamar Khan ${ }^{1}$
}

\section{ABSTRACT:}

The aim of this study was to measure different dimensions of well-being namely; physical, mental, social, emotional and spiritual, with respect to find out the difference between Hindu and Muslim students. The sample consisted of $\mathrm{N}=96(\mathrm{n}=47$ Hindu and $\mathrm{n}=49$ Muslim students) participants. Well-Being Scale prepared by Singh and Gupta (2001) was used to collect the data. The Mean, SD and t-test were used for data analyses. The findings of this study revealed that, students significantly differ with each other on physical, social, and spiritual well-being dimensions. While, there was no significant difference was found on mental and emotional wellbeing dimensions between Hindu and Muslim students. Results also showed Muslim students have higher mean score on each dimensions of well-being than the Hindu counterparts.

Keywords: Well-being, Hindu and Muslim Students.

The concept of well-being refers to individual's fullest functioning in everyday life. World Health Organization (World Health Organisation, 1952) argued optimal health as "a state of complete physical mental and social well-being and not merely the absence of disease or infirmity." They also summed spiritual well- being as one dimension of well-being. Shaffer and Shoben ( 1956) defined well-being as: (1) good physical well- being; (2) accepting one's strengths and weakness; (3) accepting other people; (4) seeking as well as having a warm feeling towards them; (5) a confidential relationship; (6) active attention; (7) social participation; (8) satisfying work; (9) creative experience; (10) using the scientific method. Scheidt (1986) conducted the study on 989 residents of small towns and found that those subjects who experienced high subjective well-being generally expressed satisfaction with living conditions social relations, and functional health.

Bower (1961) defined mental well-being as 'it is one of the degree of freedom in which an individual has to think alternatives available to deal with the stresses and strains of living.' From this point of view those people who have high mental well-being, they easily deal psychological distresses in everyday lives.

${ }^{1}$ Research Scholar, Department of Psychology, Aligarh Muslim University, Aligarh

(C) 2015 I A Khan; licensee IJIP. This is an Open Access Research distributed under the terms of the Creative Commons Attribution License (http://creativecommons.org/licenses/by/2.0), which permits unrestricted use, distribution, and reproduction in any Medium, provided the original work is properly cited. 
Schneiders (1965) proposed criteria of mental well-being as follows: (1) Mental efficiency; (2) Control and integration of motives; (3) Control of conflicts and frustrations; (4) Positive and healthy feelings and emotions; (5) Tranquility of peace of mind; (6) Healthy attitudes; (7) Healthy self concepts; (8) Adequate ego identity; (9) Adequate relation to reality. Mental wellbeing enhance our cognitive process, and to deal with simple as well as complex task. It also helps us in developing intrinsic motivation.

Social well-being concerned with social support and interpersonal relationship. Levitt et al., (1987) conducted a study on social support, perceived control and well-being. They find that social support was simultaneously related with health and personal control beliefs in relation to well-being. Their findings revealed that one close support figure can be sufficient to promote well-being. The high social well-being is a positive significance in coping with stresses of life, and developed high productivity to make effective community.

Hettler (1984) argued that spiritual dimension is one of the major elements of the well- being. He propounded a six dimension model of well-being. The main components of this model are intellectual, emotional, physical, social, occupational and spiritual. Myers(1992) conceptualized spiritual well-being as " a continuous search for meaning and purpose in life, appreciation for depth of life, the expanse of universe and natural forces which operate a personal belief system."

The present investigation was carried out to study the various dimensions of well-being among the Hindu and Muslim students. Because each dimensions have its own practical as well as clinical significance for our healthy life.

\section{OBJECTIVE OF THE STUDY}

- To determine the difference between Hindu and Muslim students on various dimensions of well-being.

\section{HYPOTHESIS OF THE STUDY}

- Hindu and Muslim students will differ with each other on various dimensions of wellbeing.

\section{Sample of the Study}

In the present research investigation sample was consisted of 96 male students $(n=47$ Hindu and 49 Muslim students), from different faculties of Aligarh Muslim University, Aligarh. The data was collected by multi-stage sampling technique.

\section{Tool Used}

In psychological researches, psychological tools play very important role especially with regard to the reliability and validity of the tools. The Well-Being Scale was used for data collection. The 


\section{A Study of Well-Being among Hindu and Muslim Students in Aligarh}

brief description of the scale used in the present investigation is presented in the following manner.

\section{Well Being Scale}

This scale was developed by Singh and Gupta (2001). This scale consisted of five sub-scale namely; physical wellbeing, mental well being, social well being, emotional well being and spiritual well being. Each sub-scale has ten items and there are 50 items in total. Scores on all the sub-scale added up to get a composite score as total well being. Minimum and maximum score can be 50 and 250 respectively. It consists of 29 positive items and 21 negative items. The testretest reliability of the scale was 0.98 and split half reliability was found to be 0.96 . Content and concurrent validity of the Well being Scale was found to be well established. Concurrent validity of the scores of well being scale was determined by comparing it with the scores of Subjective Well being Inventory Sall and Nagpal (1992).

\section{Procedure of Data Collection}

Good rapport was established with participants before requesting to fill up the questionnaire and then instructions were invariably explained to the participants. After that questionnaires were distributed individually. Subjects were assured of confidentiality of their responses and were requested to extend their co-operation. Finally questionnaires were collected from all the participants, scoring done and analysis was carried on. 
STATISTICAL ANALYSES AND RESULTS

Table-1: Showing Mean SD and t-value of Hindu and Muslim Students on various

\begin{tabular}{|c|c|c|c|c|c|}
\hline $\begin{array}{c}\text { Dimensions of Well- } \\
\text { being }\end{array}$ & Groups & $\mathbf{N}$ & Mean & SD & $\begin{array}{c}\text { t-value } \\
(\mathrm{df}=94)\end{array}$ \\
\hline \multirow{2}{*}{ Physical Well-being } & Hindu & 47 & 35.15 & 5.898 & \multirow{2}{*}{$2.25^{*}$} \\
\hline & Muslim & 49 & 37.63 & 4.649 & \\
\hline \multirow{2}{*}{ Mental Well-being } & Hindu & 47 & 33.38 & 6.163 & \multirow{2}{*}{0.37} \\
\hline & Muslim & 49 & 33.86 & 6.705 & \\
\hline \multirow{2}{*}{ Social Well-being } & Hindu & 47 & 33.19 & 6.540 & \multirow{2}{*}{$2.39^{*}$} \\
\hline & Muslim & 49 & 36.27 & 6.089 & \\
\hline \multirow{2}{*}{ Emotional Well-being } & Hindu & 47 & 33.49 & 6.043 & \multirow{2}{*}{0.89} \\
\hline & Muslim & 49 & 34.69 & 7.148 & \\
\hline \multirow{2}{*}{ Spiritual Well-being } & Hindu & 47 & 34.64 & 7.450 & \multirow{2}{*}{$2.91 * *$} \\
\hline & Muslim & 49 & 38.45 & 5.208 & \\
\hline
\end{tabular}

dimensions of Well-Being

Significant at $* * 0.01, * 0.05$ level.

In the present investigation the t-test has been applied to find out the significant difference between Hindu and Muslim students on various dimensions of well-being. The t- values on various dimensions of well-being such as physical, mental, social, emotional, and spiritual found to be $2.25,0.37,2.39,0.89$, and 2.91.The obtained t-values clearly indicate that Hindu and Muslim students are significantly differ on physical, social, and spiritual dimensions of wellbeing. While, there was no significant difference was found on mental and emotional dimensions of well-being between Hindu and Muslim students. So, these findings partially prove the hypothesis of the present investigation that 'Hindu and Muslim students will differ with each other on various dimensions of well-being.'

\section{DISCUSSION}

The obtained result shows significant difference on physical, social, and spiritual dimensions of well-being among Hindu and Muslim students. The result also shows higher mean scores on each dimensions of well-being among Muslim students as compared to the Hindu students. It means that religion have a positive impact on well-being of students. Muslim students are 


\section{A Study of Well-Being among Hindu and Muslim Students in Aligarh}

frequently involved in various religious activities. While at the same time Hindu students have been found rarely involved in religious activities and rituals. Therefore, the level of well-being on various dimensions in the case of Hindu students has been found on the lower side as compared to the Muslim students.

\section{REFERENCES}

1. Bower, E.M. (1961). Primary prevention in a school setting. In G. calpan (Ed.). Prevention of mental disorders in children. As cited by R.L. Ebel (Ed). Encyclopedia of educational research, (Forth, Editions). London: The Macmillan Company, Collier Macinillen Limited, 811-829.

2. Hettler, B. (1984). Wellness: Encouraging a life time pursuit of excellence. Health Values, 8(4), 13-17. As cited by J.E. Myers. Journal of Counseling and Development, 71(2), 136-139.

3. Levitt, M. J., Clark, M.C.., Rattan, J. and Finley, G.E. (1987). Social support, perceived control and well-being: A study of an environmentally stressed population. International Journal of Aging and Human Development, 25(4), 247- 258.

4. Myers, J.E. (1992). Wellness through the life-span. Guidepost, 11. As cited by C.K. Chandler et al. Journal of Counselling and Development, 71 (2), 168-173.

5. Scheidt, R.J. (1986). Mental Health of small-town Kansas elderly: A report from the Great Plains. American Journal of Community Psychology, 14(5), 1563-A.

6. Schneiders, A. A. (1965). Personality dynamics \& mental health-principles of adjustment \& mental hygiene. New York: Holt, Rinehart and Wiliston, Inc.

7. Shaffer, C.F. and E.J. Shoben, J. (1956). The psychology of adjustment, a dynamic and experimental approach to personality and mental hygiene. USA: Houghton Mifflin Company.

8. World Health Organisation (1952). Handbook of basic documents. (Fourth Edition). Geneva, Switzerland: World health organization, 3. 